\title{
Improvised cities: Architecture, urbanization and innovation in Peru
}

by Helen Gyger, Pittsburgh: University of Pittsburgh Press, 2019, 456 pages, US- $\$ 55.00$ (hardcover), ISBN: 9-780822-4536-3

To be published in Planning Perspectives 35.5, October 2020

Helen Gyger's book couldn't be better wrapped up than by a mid-eighteenth century quote of the viceroy Manuel de Guirior, referring to an eviction of people from the "first settlement" to a remote town ordered by him, where streets and facilities were given so "they are building houses and ranchos where they can live more obedient and civilized lives". She uses this quote in her epilogue to draw the reader's attention to a striking conclusion: enduring colonialism is still present in Peru and other Latin American contexts when it comes to understand the current realm of urban decisions and the "impacts of those decisions reverberating over time in the streets of the improvised city" (p. 375). Gyger points out the paradox that the improvised is a continuous product of a well-planned political global strategy of geopolitical dependency, and not a phenomenon due to massive migration and a lack of financial means. At the same time, she aligns urban displacement strategies and the resettling of unwanted populations to the urban periphery to a historic tradition of this practice in the Peruvian and the Latin American city - a crucial argument to be taken very seriously by policy makers who are urgently encouraged to read this truly eye-opening book.

In this sense, the book is an immensely complex and instructive analysis of the politically motivated and socially contested housing proposals in Peru, which developed over three decades (1954-1986). It is also a universal reading of the interrelations between politics and architecture/ urban planning as well as of investments and negotiations on affordable housing worldwide. In her systematic chronology laid out in a comprehensive introduction and eight chapters with most suggestive titles Gyger reveals the striking "failures at every level" (p. 376) at how to tackle immense global problems over the whole period of the cold war due to ideological blindness on all ends. This reads even more striking in moments like the global COVID-19 health crisis during which this review is written and while, another thirty years beyond, these decades of failed policies seem to be culminating in the closing of a historic cycle of migration due to a massive exodus of dwellers from the improvised city towards their rural communities of origin. Under confinement in 2020, the urban day labourers of the informal capitalist economy - in Peru and elsewhere-lose their economic livelihood and therefore any basis to subsist in the improvised city.

Out of this contemporary perspective, British economist Barbara Ward's finally unheard claim at the Habitat I Conference in Vancouver in 1976 for a "new international economic order" in a "world society" - a major reference within Gyger's account of the interrelations between housing policies and global economic interests - acquires even more relevance. Habitat I was a turning point in the international perception of the self-built and of aided self-help housing to which Peruvian ideas and experiments have largely contributed. These were both nurtured and visualized essentially by the British architect John F. C. Turner, whose working period in Peru as a consultant to the government and his significant observations and the construction of a theory on the "dwelling resources" of the barriadas, people's autogestión and self-organization converged into his book "Housing by People" (1976) as a key ideological contribution to the Vancouver gathering.

John Turner's personal archive of crucial reports, developed projects and his excellent photographic documentation of the self-built processes set, together with several interviews Gyger conducted with him, the basis for the book. Turner's "metropolitan connections" (p. 95) helped to spread his ideas and findings developed in close connection with Peruvian architectural pioneers (themselves inspired by anthropologists and dependent on their knowledge and their work based on surveys), whose decisive role in Peru's trials for housing solutions is finally given the deserved 
attention: Eduardo Neira who brought Turner to Peru and already in 1954 suggested mutual aid as traditional concept of cooperative work; Santiago Agurto who in the same year designed a growing house (casa que crece) as an incremental building model inspired by the barriadas (non-formal settlements); Federico Mevius who advocated for a carefully administered financing rather than for the dwelling and services themselves; Adolfo Córdova who diagnosed the reduced economic capacity of most Peruvians as the major cause of the housing crisis and was then a pivotal figure in the setting-up of workshops of technical assistance; and Diego Robles who also saw the key rather in the economic development than in housing and in the "officialized ayuda mutua" (p. 36) a form of domination undermining the unaided-self-help efforts, especially given Peru's structural inequality due to "its historical hierarchy of social classes within the system of internal domination and exterior dependency" (p. 301).

Gyger makes this intensive strategy search for the ample concept of aided self-help housing and urbanization as an alternative mode of practice an appropriate object of study, within "the limits - and limitations - of architecture" (p. 3) and its setbacks due to political and social impediments. She explores exactly the immense space between success and failure of the projects realized in different political periods, in a trans- and deformation of aided self-building between national and global interests and within a shifting debate on whether to understand as an individual or as a collective endeavour.

This shifting debate, the different forms of political appropriation of mutual aid and self-help and the conflictive character of the alliances between authorities, technicians and settlers become obvious through key projects that Gyger reviews carefully and critically. The evolution of the celebrated international PREVI (Proyecto Experimental de Vivienda, Experimental Housing Project) under the government of Fernando Belaúnde which had not given a solution to the provision of lowcost housing; the revolutionary government's establishment of the Sistema Nacional de Apoyo a la Movilización Social (SINAMOS) as a framework for dialogue between the government and the people which "operated at the blurred edge between the utopian and the sinister" (p. 302); the remarkable efforts of the Self-Managing Urban Community of Villa El Salvador (CUAVES) in establishing a decentralized satellite city, while "the collapse of autogestión was evident" upon invasions of reserved public land (p. 314); the communal dwelling units' experiment of Huaycán where political manipulation and the -largely tabooed-infiltration of terrorist forces complicated its promising participatory design and community building process. The final shift analysed in the book is what Gyger calls from "Freedom to build" to "Freedom to borrow" under neoliberalism, where, with the creation of a Commission for the Official Registration of Informal Property COFOPRI, illegality was "regularized" in a clientelistic gesture. Under Alberto Fujimori's regime and the imperialist umbrella of the World Bank, this political abuse of the self-help reached extreme levels of dismantling the collective forces enduring until today.

Helen Gyger's book is much more than an outstanding contribution to the "Culture, Politics and the Built Environment" series it is published in and to housing studies, urban-political history and Latin American studies: it belongs undoubtedly to the best and most meticulously researched books in these fields and is a sharp portrait of the North-South relations and their enduring effects of dependency. At the same time, it inspires the still necessary recording of the unwritten history from the people's perspective on this housing process in Peru based on the dignity, the strength and struggles, the placemaking capacities and the partially fulfilled, partially betrayed hopes of the young woman on the cover photo, as of all settlers of the improvised city. 